\title{
Study on Interest-value Theory of
}

\section{State-owned Mineral-resources}

\author{
Enzhu Li \\ School of Accounting, Shandong University of Finance, Jinan 250014, China \\ Tel: 86-531-82911094Ｅ-mail: lez11513@163.com
}

This paper is sponsored by National Natural Science Foundation of P. R. China (project No.79670094).

\begin{abstract}
This thesis, systematically introduces interest-value theory of mineral-resources, some important viewpoints, such as the value of a mining concession equals the sum of values capitalized, which include the value of mineral-resources purchased by the units of mining; the value of managerial fees collected by administrative authorities and the value of expenses occurred during exploring mineral-resources, have been summarized. On the base of interest-value theory of mineral-resources, the connotation of new management-system for state-owned mineral-resources has been also submitted. In the new management-system, establishing national trading market for mineral-resources is strongly recommended in detailed illustration. The objective of this paper is to promote the innovation of interest-value theory of mineral-resources in the world.
\end{abstract}

Keywords: Mineral-resource, Interest, Value, Theory

\section{Introduction}

Because of high-speed development of national economy, demands for the mineral-resource sharply increase, problem of mineral-resource shortage becomes more and more seriously, and change into a common key problem for human in the world. Mineral-resources, also called "diminishing assets" by experts in accounting, are one of properties depleted gradually by mining and no ways to reproduce. it needs further discussion as regards how to establish a new management-system of state-owned mineral-resources in China, which should adapt to the existing economic system. On the basis of hard work supported by the project of National Natural Science Foundation of P. R. China (project No.79670094), named Interest-value Theory and Problems of Capitalization for Mineral-resources, some personal viewpoints of interest-value theory of mineral-resources about state-owned mineral-resources should be stated by this thesis.

\section{Foundation of Interest-value Theory of State-owned Mineral-resources}

Interest-value theory of mineral-resources was proposed by the project of National Natural Science Foundation of P. R. China, The foundation of interest-value theory of state-owned mineral-resources suggested by this paper mainly embraces the following important points.

\subsection{Characteristics of Rights and Interests of Sate-owned Mineral-resources}

Characteristics of interests of sate-owned mineral-resources listed below:

\subsubsection{Mineral-resources must be utilized efficiently}

Because of the economic value of mineral-resources stemming from surplus value of human labor, only mineral-resources were utilized efficiently, the profits of the mineral-resources should be realized, If mineral-resources were utilized invalidly, no interests of the mineral-resources should be gained.

\subsubsection{Value incarnated by transaction in the trading market of property rights of mineral-resources}

Before state-owned mineral-resources transferred, the total value of the interests of state-owned mineral-resources attribute to the nation. With the reform of the management-system in China, the mineral-resources would enter the trading market of property right of mineral-resources for transaction. The units of mining should purchase the right of mining or a mining concession at the cost of market quotation, and then the rights and interests of mineral-resources would be transferred to the purchasers, which would possess rights and interests of mineral-resources purchased. In this point, rights and interests of state-owned mineral-resources are differ from rights and interests of land, as we know, only the usage-right of the land can be transferred each other, no property-right of the land can be transferred now in P. R. China. So the sate-owned ownership of the land determines that earnings of transferring a mining concession of 
state-owned mineral-resources belong to nation or the entire people, and also is a result of economic realization on property right of sate-owned ownership of mineral-resources.

\subsection{Main Modes of Mineral-resources in the World}

Economists devote much attention to the study of economic essential of mineral-resource. Many scholars, like Conrad J. M (Conrad J. M \& Clark C. W, 1987) and Randel A (Randel A, 1987), proposed their opinions for protecting mineral-resource or researching the value of mineral-resource in the word. Mineral-resources being considered as assets become an important subject of studying economic essential of mineral-resource in China (Zhu, Xueyi \& Li, Enzhu, 1999, pp. 29-38).

Because of differences between the social system, the economic system and the statutory rules of every countries in the world, the ownerships of land and means of production are different also, so differences between the modes of rights and interests of mineral-resources exist reasonably, main modes of rights and interests of mineral-resources listed in Table 1. This is the beginning of studying management-system of state-owned mineral-resources.

\section{Connotation of Interest-value Theory of Mineral-resources}

\subsection{Total value of mineral-resources should be capitalized}

In order to establish new theory of mineral-resources, the total value of mineral-resources should be capitalized to an account, then the mineral-resources capitalized can be managed as assets, this content is the core of the innovation of the theory. The values of mineral-resources capitalized are illustrated bellow.

\subsubsection{Value of mineral-resources purchased by the units of mining should be capitalized}

If exploiting mineral-resources, the units of mining must purchase a mining concession in advance and value of mineral-resources purchased by the units of mining should equal the value of a mining concession of the units of mining, and should be capitalized into an asset of mineral-resources, which should include the acquisition price, all taxes and fees in deal of purchasing mineral-resources or a mining concession. The asset of mineral-resources or the intangible asset of a mining concession should be transferred as the form of deletion or amortization into the costs of mineral products during procedure of production, and compensated with sale of mineral products gradually. In order to prevent illegal deals and be convenient for management, trading market for property right of mineral-resources, especially, the big integrated market will be suggested by this paper.

\subsubsection{Value of managerial fees collected by administrative authorities should be capitalized}

Due to execute the administrative obligations, administrative authorities may collect some managerial fees from the units of mining. These values of managerial fees collected by administrative authorities should also be capitalized, as above mentioned, these capitalized values will also be transferred into the costs of mineral products during procedure of production, and also compensated with sale of mineral products gradually. The main managerial fees would include following items:

\subsubsection{Fee of protecting environment}

During mineral-resources developed, environment may be polluted and ecological equilibrium may also be broken. In order to prevent these situations, administrative authorities must take effective measures to recuperate foundation of environment, improve the quality of ecological environment and keep proper rate of exhaustion of mineral-resources, so the fee of protecting environment must be imposed.

\subsubsection{Fee of developing substitute resources}

There is a reserves limitation of existing mineral-resources. Before exhaustion of the mineral-resources, research on new substitute resources, development of new utilization to known mineral-resources and study of new functions of existing mineral products should be arranged by the administrative authorities, so the fee of developing substitute resources must be collected for organizing such works mentioned above.

\subsection{Value of expenses occurred during exploring mineral-resources should be capitalized}

Discovery-right, similar to the patent right of intangible assets, should belong to the prospector or units of exploration and the interests of discovery-right also belong to. Discovery-right should be transferred to the units of mining ungratuitously, the interest of the prospector or units of exploration in the transaction equals the net proceeds that is remainder of transfer price deducts the cost of exploration and the taxes and fees of assignment. The interest of discovery-right should be included in acquisition price or taxes and fees in deal of purchasing mineral-resources or a mining concession. Expenses occurred during exploring mineral-resources would include the following items:

\subsubsection{Fees of application for enrollment}

If prospecting mineral-resources, according to statutes, the prospector or units of exploration must apply for prospecting-right in advance, and must pay some fees for this action, so the Fees of application for enrollment should be 
calculated and capitalized to the value of mineral-resources.

\subsubsection{Practical expenditure occurred during exploring}

Geological prospecting is a long process which combines the mental work with physical labor. First, it needs the theoretical inference and scientific research; second, it passes the courses of general investigation, detailed survey by prospecting technique even the high- technique means. The whole course is likely to last for 2-5 years as short and more than 10 years as long, and many items of practical expenditure occurred during this exploring course, so these expenses occurred during exploring mineral-resources should be calculated and capitalized to the value of mineral-resources certainly.

\section{Key Utilization of Interest-value Theory of State-owned Mineral-resources}

With the system reform of property right becoming deeply in P.R. China, multi-subjects of property right connected by capital provide conditions for transferring value of mineral-resources un-gratuitously. One of crucial points of the utilizations submitted by this thesis is to increase national revenue of the existing taxes and fees in the trade of property rights of mineral-resources. The first reason for this point is that the lower standard of imposing taxes and fees of mineral-resources could not reflect the values of interests of sate-owned mineral-resources; the values of managerial fees collected by administrative authorities and the values of expenses occurred during exploring mineral-resources, the second reason is that the lower standard of imposing taxes and fees also could not effectively eliminate extra profits caused by the differences between mineral-resources, and could form unfair competitions between mining enterprises. The inevitable results of unfair competitions would cause striving for better mineral-resources, also cause ignoring safe inputs, the technical and managerial improvement and the effective recovery ratio of mineral-resources in mining production. For example, in coal mining industry of mainland, China, because of the lower standard of imposing taxes and fees of mineral-resources, the average recovery ratio of coal mineral-resources only reached about $40 \%$ by the end of Sept. 2006, this ratio may be lower about 25 percentage points than the same ratio of the other main countries of mining coal resources in the world (Liu, Shunguo, 2006, pp. 2-4). On the basis of interest-value theory of mineral-resources, implementing business of results of geological prospecting and establishing integrated trading market for property right of mineral-resources would be two key substances of innovation proposed by this paper for state-owned mineral-resources. Detailed explanations are given below.

\subsection{Put the Results of Geological Prospecting into the Course of Trade}

The procedure of implementing business of results of geological prospecting should be divided into two steps on the basis of realistic status in P. R. China. The first, when determining the value of mineral-resources in existing mining enterprises, administrative authorities of the nation would recover the surplus value in results of geological prospecting as partly withdrawing the fund invested to field of geological prospecting by nation before. The second, in order to impel the formation of operating system in units of geological prospecting, national financial allocation to the units of geological prospecting would be decreased by degrees and even stricken off.

\subsection{Establishing National Trading Market for Property Right of Mineral-resources}

For the sake of management, national trading market for property right of mineral-resources will be suggested by this paper. The procedure of establishing national trading market for property right of mineral-resources also should be divided into two steps on the basis of realistic status in P. R. China.

\subsubsection{Determining the value of mineral-resources in existing mining enterprises}

The workable reserves and the grades of existing mining enterprises should be examined and approved again on the basis of different factors,such as ore grade; geological conditions; mining degree of difficulty; conditions of communications and transportation, the better of the factors mentioned above are, the higher the grades and the value of the mineral-resources are. The grades and the value of the mineral-resources would be the basis for imposing related taxes and fees of the existing mineral-resources. The methods related costs or proceeds, such as method of present value; method of net price and so on, can be used to confirm the value of mineral-resources. After the total value has been calculated for a block of mineral-resources, then this block of mineral-resources must be transferred to the receiver according to the quotation of price in the national trading market for property right of mineral-resources, proposed by this thesis.

\subsubsection{A mining concession should be purchased by the new mining enterprises}

A mining concession should be purchased by the new mining enterprises according to the quotation of price in the national trading market for property right of mineral-resources in advance. When mining enterprises newly founded need developing mineral-resources, new units of mining should purchase a mining concession for extracting in the national market. The property right of sate-owned mineral-resources newly discovered also should be transferred to the receiver or new units of mining in the national market. The value of a mining concession equals the sum of values capitalized , which include the value of mineral-resources purchased by the units of mining; the value of managerial fees 
collected by administrative authorities and the value of expenses occurred during exploring mineral-resources.

\section{Conclusions}

In order to maintain stable, sustained and coordinated development of national economy, it is an important task to manage and utilize the limited mineral-resources effectively for China, as a developing country. Because of system of planned economy, mineral-resources were allocated by means of plans in past decade years. The mode of economic growth depending on high consumption and input of mineral-resources have been formed naturally, thus large amount of mineral-resources have been wasted. On this background, the interest-value theory of mineral-resources has been studied first, and some important viewpoints, such as the value of a mining concession equals the sum of values capitalized ,which include the value of mineral-resources purchased by the units of mining; the value of managerial fees collected by administrative authorities and the value of expenses occurred during exploring mineral-resources, have been summarized by the first step in the study of interest-value theory of mineral-resources. The direction of future research would be toward specific items such as the rules of trade, the methods of value calculation for mineral-resources capitalized and so on. With development of research on interest-value theory of mineral-resources, the management theory for state-owned mineral-resources will become perfectly, and would play more important roll in development of national economy.

\section{References}

Conrad J. M \& Clark C. W. (1987). National Resources Economics, Notes and Problems. New York:Cambridge University Press.

Liu, Shunguo. (2006). Study on Marketing of Coal Resources. Journal of Economic Problem. 9: 2-4 (In Chinese).

Randel A. (1987). Resources Economics-An Economics Approach to Natural Resources and Environmental Policy. New York: John Wiley \& Sons.

Zhu, Xueyi \& Li, Enzhu. (1999). Study on Mining Mineral-resources with Compensation. Xuzhou: Press of China University of Mining and Technology. 29-38 (In Chinese)

Table 1.Comparisons between modes of rights and interests of mineral-resources in the world

\begin{tabular}{|c|c|c|c|}
\hline Modes & $\begin{array}{l}\text { System of ownership } \\
\text { of the land }\end{array}$ & $\begin{array}{l}\text { System of separation } \\
\text { from two rights }\end{array}$ & System of national right \\
\hline Main intension & $\begin{array}{l}\text { Mineral-resources } \\
\text { belong to owner of } \\
\text { land. Only the owner } \\
\text { of land and } \\
\text { authorized members } \\
\text { of owner of land can } \\
\text { do prospecting, } \\
\text { exploiting and using } \\
\text { mineral-resources. } \\
\text { The government can } \\
\text { restrain the action of } \\
\text { the owner of land }\end{array}$ & $\begin{array}{l}\text { Property right of } \\
\text { mineral-resources } \\
\text { separates from the } \\
\text { right of land. } \\
\text { Property right of } \\
\text { mineral-resources } \\
\text { are awarded to } \\
\text { prospectors and the } \\
\text { users by the } \\
\text { government }\end{array}$ & $\begin{array}{l}\text { Legal rules stipulate that property } \\
\text { right of mineral-resources, as } \\
\text { wealth of the nation or the entire } \\
\text { people, belong to nation or } \\
\text { sate-owned enterprise, which can } \\
\text { do prospecting, exploiting and } \\
\text { using the mineral-resources, the } \\
\text { rules also stipulate items for } \\
\text { attention and distribution of } \\
\text { benefits. The government obtains } \\
\text { earnings by transactions of } \\
\text { sate-owned mineral-resources, } \\
\text { tax revenue and profits of } \\
\text { sate-owned mining enterprise. }\end{array}$ \\
\hline $\begin{array}{l}\text { Representative } \\
\text { countries }\end{array}$ & The U.S,the U.K, etc. & $\begin{array}{l}\text { Countries } \\
\text { Euro-land (such as } \\
\text { France), Japan etc. }\end{array}$ & $\begin{array}{l}\text { P. R. China and most of } \\
\text { developing countries }\end{array}$ \\
\hline
\end{tabular}

